\title{
Professional Skills Development Affecting Organizational Learning and Corporate Performance: An Empirical Study in Thailand
}

\author{
Alisara Saramolee ${ }^{1}$, Yuttachai Hareebin ${ }^{2}$, Sunthorn Boonkaew ${ }^{1}$, \\ Somnuk Aujirapongpan ${ }^{1}$, Jaturon Jutidharabongse ${ }^{1}$ \\ ${ }^{1}$ School of Management, Walailak University, Tha Sala, 80160, Nakhon Si Thammarat, Thailand \\ ${ }^{2}$ Faculty of Management Science, Phuket Rajabhat University, Muang, 83000, Phuket, Thailand
}

\begin{abstract}
This research aims to describe the factors and patterns of relationships involved in dominant professional skills development by focusing on social skills that influence organizational learning for business sustainability and operational efficiency enhancement. The research provides guidelines that hotel businesses in Phuket Province can use to implement strategies in a currently rapidly-changing and competitive environment. This study shows that professional and social skills influencing the organizational performance of the hotel businesses in Phuket include communication, leadership, problem solving, and teamwork skill. This analytical result is based on resource-based and service innovation theories and can be used to improve organizations operating performance.
\end{abstract}

Keywords - social skills, learning organization, corporate performance, hotel businesses.

\section{Introduction}

Thailand has followed its 12th National Economic and Social Development Plan of 1997-2021.

DOI: $10.18421 /$ TEM111-29

https://doi.org/10.18421/TEM111-29

Corresponding author: Somnuk Aujirapongpan, School of Management, Walailak University, Tha Sala, 80160, Nakhon Si Thammarat, Thailand

Email: asomnuk@wu.ac.th

Received: 21 July 2021.

Revised: 29 January 2022.

Accepted: 05 February 2022.

Published: 28 February 2022.

(c) BY.NC-ND (C) 2022 Alisara Saramolee et al; published by UIKTEN. This work is licensed under the Creative Commons Attribution-NonCommercial-NoDerivs 4.0 License.

The article is published with Open Access at https://www.temjournal.com/
This national plan was aimed at achieving sustainability through economy philosophy and human capital-driven development approaches. Concurrently, the Thailand 4.0

Model, adopting a prosperous, stable and sustainable vision, was developed as a key strategy for national development by General Prayuth ChanOcha, Prime Minister and Head of the National Council for Peace and Order. According to this national strategy and development plan, Thailand would be restructured and dynamically developed into a value-based economy driven by innovation and technology. Another focus of this national strategic and development plan has included the enhancement of national competitiveness and the medium-tohigher income trap. According to this plan, the deployment of R\&D and human capital development has been strategically fostered in transforming the workforce from an unskilled population to a knowledgeable and skilled workforce. In responding to this change, most organizations prioritized human resource development and developed their workforces in innovation, creativity and productive capabilities. Workforce capability development, therefore, involves an innovative organization attaining greater business competitiveness for entrepreneurs [1], [2]. In the tourism and hospitality industry, especially for hotel businesses, competitiveness has become an essential means of gaining business advantages and plays a key role in today's business operations. In the past, successful hotels often offered numerous rooms, facilities and services. This approach to running hotel businesses has increasingly shifted to a focus on competing in providing products and services based on differentiation strategies and the latest technologies and innovations. Hotel owners, therefore, have had to rethink their operational strategies and provide products and services in a newly articulated style aimed at attaining a competitive advantage in the business environment [3], [4]. 
As mentioned above, this change in hotel business has required immediate strategic revisions to human resource development to anticipate workforce competitiveness, especially in terms of soft skills or emotional and social skills, which are increasingly identified as required in the 21 st Century. An employment survey of more than 400 establishments in the USA found that most employers seek staff with essential working skills, i.e., professional ethics, communication, teamwork, critical thinking, and problem-solving skill [5], [6]. Indeed, these skills seem to be becoming more important than hard skills. Accordingly, $50 \%$ of respondents of another survey of more than 2,000 employers identified "soft skills "as the most important work skills [7]. [8] corroborate this result by showing that $15 \%$ of hard skills and $85 \%$ of soft skills are relevant to individual success. Soft skills, therefore, are some of the most important competencies that stimulate success in individual tasks, income and career development as well as responding to organizations ' needs for productivity [9]. Organizations have partially substituted their workforces with technology. However, "soft skills" are still essential to organizational productivity in the workforce and in human development and will never be replaced by technology [10], [11]. As mentioned above, the increased significance of soft skills and problems has arisen from social change in knowledge-based economies; similar to organizations in general, hotels and hospitality firms have needed to develop their workforces' professional skills in responding to the needs of customers and immediately adapting new technologies. As such, organizational capability in service quality can be improved, requiring investment in and the retention of a knowledgeable and professionally equipped workforce to develop organizations characterized by sustainable human capital development and life-long learning [12], [13].

Therefore, hotel businesses, which operate in highly competitive environments, often implement strategies relying on the use of innovative technologies in creating and gaining a competitive advantage. The workforce has become one of the most important resources in such a competitive business setting. In this study, we examined types of dominant practical and professional skills used with a focus on social skills that affect learning organization and corporate performance. Heads and directors of human resources departments of 5-star hotels in Phuket served as key respondents to identify the relationships and useful directions for human resource development for hotel businesses.

\section{Literature Review}

\subsection{Social Skills}

Social skills shape the ways that individuals work and their personality, habits, attitudes, and behavior; internally and interpersonally intangible competencies contribute to individuals' growth, learning and task accomplishment, and help enhance an organization's effective performance [9], [14], [15]. Following [16] classification, the following four types of social skills are studied in this research: 1) communication, 2) leadership, 3) problem solving, and 4) teamwork skills. More details on each of these types of social skills are provided as follows:

\subsubsection{Communication skills}

Social interaction involving the use of symbols, posture and messages whereby the sender initiates a process resulting in stimulation, i.e., using verbal and written language to change the behaviors of others or message receivers [17], [18]. In general, communication skills can take three forms.

Personal communication - two or more people exchange information via face-to-face communication;

Organization communication - information exchange occurs between individuals at all levels of an organization whereby individuals interactively communicate for relevant purposes within an organizational environment [19] and

Nonverbal communication - a message and its meaning is disseminated using neither verbal nor written language but via the interpretation of interpersonal distance or boundaries, i.e., gender, ethnicity, personality, and body language [20].

\subsubsection{Leadership skills}

Individuals directly and indirectly influencing organizations to anticipate targeted goals by using their vision and intelligence for problem solving and encouraging personnel to accomplish tasks purposefully and effectively [21]. Leaders naturally initiate a process and encourage colleagues and subordinates to follow, change their intentions, and develop their capabilities in raising their awareness of the mission and vision of an organization where team members specifically engage in four behaviors [22].

Inspiration motivation - leaders support their subordinates by motivating them to challenge themselves, engage in self-improvement, exceed expectations, and rationalize the goals and outcomes anticipated from their increased motivation.

Idealized influence - leaders are ethical and visionary. 
Individualized consideration - leaders pay intention to individual matters and subordinates' actions at the individual level, i.e., via training and recommendations.

Intellectual stimulation - leaders encourage their subordinates to become knowledgeable and improve their critical thinking skills, reasoning, and prudence in tackling problems.

\subsubsection{Problem-solving skills}

Applying one's experience previously initiated by fundamental learning in solving problems in a new situation or dealing with new problems. Problemsolving is a learning skill that relies on two or more relevant principles and combining them, resulting in new problem-solving abilities. Means of solving problems to attain expected goals are dependent on individual's competencies, including his or her level of maturity, experience, interests, intelligence, readiness, emotional motivation, and environmental context [23]. Similarly, [24] identified consciousness and intelligence as influencing problem-solving skills and helping individuals solve problems effectively, motivation, which initially drives problem solving, and decision making that appropriately addresses problems.

\subsubsection{Teamwork skills}

Two or more individuals work together, share/allocate responsibilities and tasks among themselves and work as a team via interactive relationships and good communication based on agreed upon/established goals [25], [26]. As we focus on hotel employees, elements for teamwork skills considered include self-responsibility toward the team's success, collaboration with colleagues, support from other team members, and the capacity for goal accomplishment.

\subsection{Learning Organization}

A learning organization exhibits outstanding learning capacities following a systematic pattern prevalent throughout the entire organization. Additionally, organizations support all individuals'learning, continuously improve and change to enhance individual learning at all levels and create learning value that institutionally contributes to the organizational culture [27], [28]. Following [12] and [13], a learning organization can be described as exhibiting the following five characteristics.

Personal mastery - individual learning involves striving for behavioral learning and seeking knowledge to facing changes that can occur at any time .Individual learning should cover all matters, i.e., learning, thinking, practicing, and anticipating desirable outcomes.

Mental model - an ideal viewpoint expresses how individuals understand matters based on their accumulated experience in an environment, forming patterns of thinking. Any organization should support their staff members in implementing this mental model, practicing, and ambitiously pursuing their learning.

Shared vision - organizational members are aware of commonly planned goals to be anticipated. As such, a shared vision is essential to operational management in the modern era. Any process implemented at the organizational level should be established using a shared and clear vision acknowledged by all individuals involved.

Team learning - learning generates a variety of thoughts or ideas for organizations to make the most beneficial decisions. Team learning, therefore, should facilitate and encourage all team members to optimize their capabilities while working.

System thinking - this form of thinking is at the heart of learning organizations and links thinking, rationales and synergies into a system of dependencies, relationships and continuous patterns. System thinking creates a shift in perspective. Once problems occur, all team members alter their ways of understanding problems by determining whether they have resulted from their colleagues, the external environment or their own actions.

\subsection{Corporate Performance}

Corporate performance refers to a composite assessment of how well an organization is performing on its most important parameters. Analyzing organizational performance is an integral part of business analytics. It is relevant to the health of the organization, which is typically measured in terms of financial performance [29]. [30] studied funding readiness and business performance relationships and found that data capital availability has a direct positive effect on business performance. In recent years, however, the concept of corporate health has expanded, as has the concept of business sustainability. Currently, corporate health is considered relevant not only to financial considerations. Social responsibility factors, reputation, innovation, employee morale and productivity are also important [31]. This result is in line with [32], who state that corporate performance reporting takes into account not only financial criteria but also those that reflect both internal and external environments .It is also known that activities of learning organizations have a direct impact on the efficiency of corporate performance [33]. 
From the literature on social skills and learning organizations, the researchers developed a conceptual framework using DE = direct effects, IE =indirect effects, TE $=$ total effects, ) $* \mathrm{P}<.0 .05(,)^{*} * \mathrm{P}<.0 .01$ ( as shown in Figure 1.

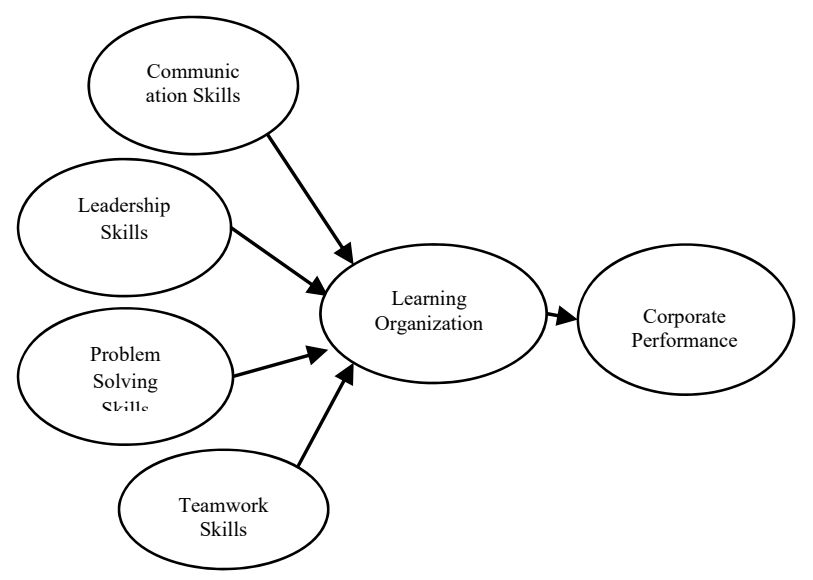

Figure 1. Conceptual research framework

\section{Methodology}

\subsection{Population and sampling}

This research relied on a quantitative approach. The researchers obtained the study population from the Phuket Personnel Management Club consisting of a total of 2,862 hotels. Samplings were purposefully identified, and respondents were personnel managers or directors of the human resource departments of 5star hotels in Phuket.

\subsection{Data Analysis}

The research employed a survey using 5-point Likert. A total of 69 questions were developed, with the content validated by five external experts. Only 64 questions were deemed valid, achieving the minimum IOC scores. The reliability of the 64 questions was initially tested with 119 respondents or $31.19 \%$ of the sample. Table 1. shows Cronbach's alpha coefficients of high confidence levels exceeding 0.700. Data collection, based on the conditions of structural equation analysis, required another sample of 280 , resulting in a sufficient ratio of 20 to 1 variables [34]. A total of 392 (out of 400) respondents completed the questionnaires.

Table 1. Results of Cronbach's alpha coefficient

\begin{tabular}{lc}
\hline \multicolumn{1}{c}{ Variables } & Cronbach's Alpha \\
\hline Communication skills (CS) & 0.817 \\
Leadership skills (LS) & 0.825 \\
Problem solving skills (PSS) & 0.834 \\
Teamwork skills (TS) & 08.96 \\
Learning organization (LO) & 0.827 \\
Corporate performance (CP) & 0.883 \\
\hline
\end{tabular}

The data analysis involved three steps. First, a confirmatory factor analysis was employed to study the consistency of structural equation modeling (SEM) with evident information. Then, Pearson's product-moment coefficient was applied to analyze the relationship between each element and factor. At this stage, the researchers used SPSS to analyze the results. Finally, analytical testing of the SEM was employed to confirm the consistency of the model developed by the researchers from information collected from 392 survey questionnaires using the LISREL program.

\section{Results and Discussion}

\subsection{Confirmatory Factor Analysis}

After testing all six elements of the constructed model with a total of 14 observed variables denoting statistical values obtained before and after adjusting the model based on comparative criteria as recommended by [35], the analytical results of the initial testing did not seem to be confirmed by evident information. Therefore, we adjusted the model until the confirmatory test results were obtained $(\chi 2=164.09, \mathrm{df}=87, \chi 2 / \mathrm{df}=1.89, \mathrm{P}$-value $=$ $0.00018, \mathrm{GFI}=0.92$, AGFI $=0.92$, RMSEA $=0.035$, RMR $=0.024)$. For factor loading values, the results positively show a significant shift from 0 at a statistical significance of 0.1 , and the values range between 0.672 and 0.854 (see more details in Table 2.).

Table 2. Composite reliability values

\begin{tabular}{ccccc}
\hline \multirow{2}{*}{ Construct } & Indicators & $\begin{array}{c}\text { Factor } \\
\text { Loading }\end{array}$ & t-value & R2 \\
\hline \multirow{3}{*}{ CS } & CS 1 & 0.672 & 11.593 & 0.079 \\
& CS 2 & 0.772 & 12.421 & 0.453 \\
& CS 3 & 0.771 & 9.289 & 0.611 \\
LS & LS 1 & 0.763 & 11.077 & 0.627 \\
& LS 2 & 0.785 & 11.593 & 0.539 \\
& LS 3 & 0.804 & 12.421 & 0.514 \\
PSS & PSS 1 & 0.800 & 9.289 & 0.385 \\
& PSS 2 & 0.668 & 11.228 & 0.499 \\
& PSS 3 & 0.750 & 11.201 & 0.748 \\
TS & TS 1 & 0.792 & 12.014 & 0.722 \\
& TS 2 & 0.678 & 9.258 & 0.766 \\
& TS 3 & 0.708 & 10.380 & 0.078 \\
LO & LO 1 & 0.785 & 12.014 & 0.132 \\
& LO 2 & 0.854 & 11.749 & 0.766 \\
& LO 3 & 0.752 & 12.253 & 0.161 \\
CP & CP 1 & 0.563 & 8.458 & 0.514 \\
& CP 2 & 0.844 & 12.899 & 0.385 \\
& CP 3 & 0.754 & 11.431 & 0.499 \\
\hline
\end{tabular}

Notes: $\chi 2=164.09, d f=87, \chi 2 / d f=1.89, P$-value $=0.00018, G F I=$ $0.92, A G F I=0.92, R M S E A=0.035, R M R=0.024$ 
In addition, from the matrix of correlation coefficients among the variables at a significance level of 0.01 , the strongest relationship was found between relationship skills and corporate performance (0.88). The second strongest relationship of 0.72 was found between leadership skills and teamwork skills. See more details in Table 3.

Table 3. The correlation of Pearson's product-moment coefficient

\begin{tabular}{ccccccc}
\hline Variables & CS & LS & PSS & TS & LO & CP \\
\hline CS & 1.00 & & & & & \\
LS & 0.65 & 1.00 & & & & \\
PSS & 0.63 & 0.42 & 1.00 & & & \\
TS & $0.71 * *$ & $0.72 * *$ & $0.63^{* *}$ & 1.00 & & \\
LO & $0.40^{* *}$ & $0.41^{* *}$ & $0.51 * *$ & $0.64^{* *}$ & 1.00 & \\
CO & $0.52^{* *}$ & $0.88^{* *}$ & $0.67^{* *}$ & $0.69^{* *}$ & $0.67 * *$ & 1.00 \\
\hline
\end{tabular}

Notes: $N=292$; significance at: $* * p<0.01$ and $* p<0.05$ (twotailed)

\subsection{Analysis of Hypothesized Model}

The SEM was tested to determine how well the model fit the information. The analytical results of Model 1 reveal that $\chi 2=642.02, \mathrm{df}=284, \chi 2 / \mathrm{df}$ $=2.26, \mathrm{P}$-value $=0.00000, \mathrm{GFI}=0.97$, AGFI $=0.80$, RMSEA $=0.052$, and RMR $=0.020$; and $\chi 2 /$ df value of 2.26 (exceeding 2); and an RMSEA value of 052.0 )higher than 0.05). These analytical results confirm that the model fits the observed data. The test of Model 2 shows that $\chi 2=432.52$, df $=297, \chi 2 / \mathrm{df}$ $=1.45, \mathrm{P}$-value $=0.00000, \mathrm{GFI}=0.98, \mathrm{AGFI}=0.92$, RMSEA $=0.042$, and RMR $=0.022$. According to this analytical testing of Model 2, all of the values acceptably confirm that the model fits the observed data.

The analytical results of causal relationships identify that learning organization status is directly related to corporate performance at a significance level of 0.01 and with a path coefficient of $\mathrm{DE}=$ 0.34. Communication skills show a direct relationship with learning organization status at a significance level of 0.05 with a path coefficient of $\mathrm{DE}=0.33$ and show direct and indirect relationships with corporate performance through learning organization status at a significance level of 0.05 with path coefficients of $\mathrm{DE}=0.14, \mathrm{IE}=0.12$, and TE $=0.26$. Leadership skills show a direct relationship with learning organization status at a significance level of 0.05 with a path coefficient of $\mathrm{DE}=0.22$. Direct and indirect relationships with corporate performance through learning organization status were found at a significance level of 0.05 with path coefficients of $\mathrm{DE}=0.29, \mathrm{IE}=0.11$, and $\mathrm{TE}=0.40$. For problem solving skills, a direct relationship with learning organization status was found at a significance level of 0.05 with a path coefficient of $\mathrm{DE}=0.23$. Direct and indirect relationships with corporate performance through learning organization status were identified at a significance level of 0.05 with path coefficients of $\mathrm{DE}=0.23, \mathrm{IE}=0.05$, and $\mathrm{TE}$ $=0.28$. Finally, teamwork skills show a direct relationship with learning organization status at a significance level of 0.05 with a path coefficient of $\mathrm{DE}=0.32$. Direct and indirect relationships with corporate performance through learning organization status were identified at a significance level of 0.05 and with path coefficients of $\mathrm{DE}=0.39, \mathrm{IE}=0.18$, and $\mathrm{TE}=0.57$. The analytical results are shown in Table 4. and Figure 2.

Table 4. Path coefficient and hypothesis testing

\begin{tabular}{cccccccc}
\hline \multirow{2}{*}{$\begin{array}{c}\text { Dependent } \\
\text { Variable }\end{array}$} & $\mathrm{R}^{2}$ & \multirow{2}{*}{ Effect } & \multicolumn{6}{c}{ Independent Variable } \\
\cline { 4 - 8 } & & & $\mathrm{CS}$ & $\mathrm{LS}$ & $\mathrm{PSS}$ & $\mathrm{TS}$ & $\mathrm{LO}$ \\
\hline \multirow{3}{*}{$\mathrm{LO}$} & \multirow{2}{*}{0.40} & $\mathrm{DE}$ & $0.33^{* *}$ & $0.22^{*}$ & $0.23^{*}$ & $0.32^{*}$ & \\
& & $\mathrm{IE}$ & - & - & - & - & \\
& & $\mathrm{TE}$ & $0.33^{* *}$ & $0.22^{*}$ & $0.23^{*}$ & $0.32^{*}$ & \\
$\mathrm{CP}$ & 0.72 & $\mathrm{DE}$ & $0.14^{*}$ & $0.29^{*}$ & $0.23^{*}$ & $0.39^{* *}$ & $0.34^{* *}$ \\
& & $\mathrm{IE}$ & $0.12^{*}$ & $0.11^{*}$ & $0.05^{*}$ & $0.18^{* *}$ & - \\
& & $\mathrm{TE}$ & $0.26^{*}$ & $0.40^{*}$ & $0.28^{*}$ & $0.57^{* *}$ & $0.34^{* *}$ \\
\hline
\end{tabular}

Notes: $D E=$ Direct Effect, $I E=$ Indirect Effect, $T E=$ Total Effect, $*(P<.0 .05), * *(P<.0 .01)$

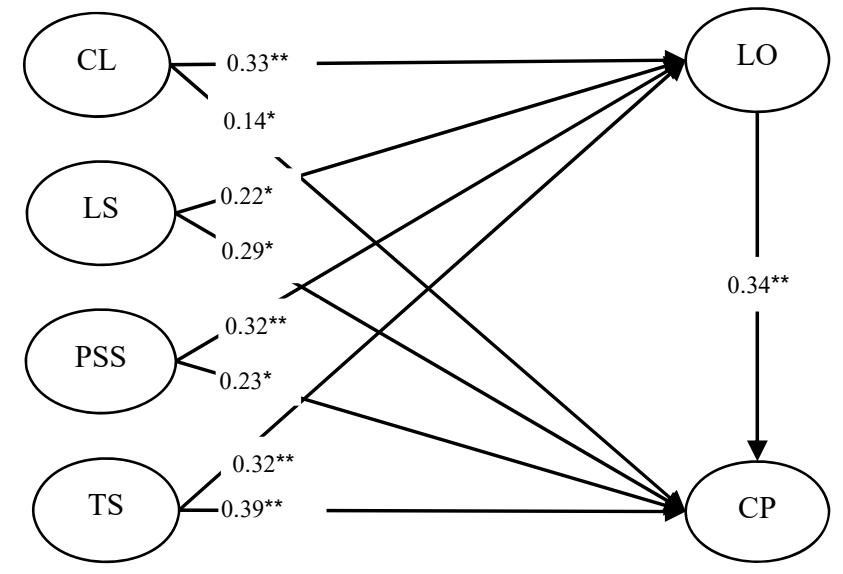

$\chi 2=432.52, d f=297, \chi 2 / d f=1.45, P$-value $=0.00000, G F I=0.98$, $A G F I=0.92, R M S E A=0.042, R M R=0.022$

Figure 2. Testing results of conceptual framework

The results of the analysis of relevant and important social skills influencing learning organizations are as follows: Results for the communication skills of learning organizations, including i) interpersonal, ii) organizational, and iii) nonverbal communication for 5-star hotels in Phuket, reveal that interpersonal communication shows a positive relationship valued at 0.474 with personal mastery. For organizational communication, we found a positive relationship of the 481.0 level with shared vision. Additionally, nonverbal communication shows a positive relationship of the 501.0 level with critical thinking. These three 
communication skills with statistical significance (0.1) confirm that employees' communication skills can help hotels become learning organizations, as previously shown by [36].

Leadership skills in learning organizations, including i) inspirational motivation, ii) idealized influence, iii) individualized consideration, and iv) intellectual stimulation for 5-star hotels in Phuket, show different positive relationships. These included positive relationships of the 0.468 level between inspirational motivation and critical thinking, of the 0.442 level between idealized influence and critical thinking, of the 0.585 level between individualized consideration and critical thinking, and of the 0.539 level between intellectual stimulation and critical thinking. These four leadership skills, as statistically found at the 0.1 significance level, confirm that leaders heavily influence colleagues and subordinates in developing capabilities in and awareness of organizational and team missions and visions [22]. Accordingly, as [37] stated, leaders influence their teams and thus leaders' characteristics affect team learning and efficiency in operational development and learning among team and organizational members.

Problem-solving skills in learning organizations, including i) intelligence, ii) a readiness to address problems, and iii) decisive options in addressing problems for 5-star hotels in Phuket, were found to have varying positive relationships with critical thinking. These include positive relationships of the 0.591 level between intelligence and critical thinking, of the 0.668 level between a readiness to address problems and critical thinking, and of the 0.657 level between decisive means to address problems and personal mastery. These three problem-solving skills, as statistically found at the 0.1 significance level, confirm creative thinking and problem-solving patterns previously studied by [38], showing that personal knowledge or expertise constitute creative problem solving alongside a stimulus model of thinking and creative problem solving.

Teamwork skills in learning organizations, including i) self-responsibility for team success, ii) collaboration with colleagues, and iii) supporting team members in accomplishing goals for 5-star hotels in Phuket, were found to show varied statistical relationships. These include positive relationships of the 0.632 level between selfresponsibility for team success and personal mastery, of the 0.666 level between collaboration with colleagues and personal mastery, and of the 0.686 level between supporting team members in accomplishing goals and personal mastery. Statistical results of a significance level of 0.1 for all 3 teamwork skills show that hotel employees work as a team and shared their knowledge, eventually resulting in personal mastery. In addition, hotel employees' learning not only focuses on professional matters but also on other relevant areas, and employees can teach or train their colleagues and subordinates using the pattern, concept and operational practices of the quality, corroborating the results of [39].

\section{Conclusion}

According to the results found in this research, the development of employees' professional skills at 5star hotels in Phuket and of learning organizations based on perspectives on social skills is discussed below.

First, the development of communication skills for hotel employees covers four basic skills - speaking, writing, nonverbal communication, and listening. In particular, listening skills were found to be fundamental to effective communication. Communication skills training with colleagues should focus on proper ways to improve employees' effective and professional communication skills.

Second, the development of leadership skills for hotel employees involves attempts to encourage individuals to personally improve their leadership skills. This guideline is fundamentally underpinned by moral and ethical practices. In addition to demonstrating a caring disposition, respect for others, emotional maturity, openness to other opinions, positive human relations, a role model with leadership skills can influence his or her colleagues and subordinates. However, practicing leadership skills might take time, and organizations should encourage their employees to participate and share their ideas and provide opportunities for them to develop their interests, practice becoming leaders, and engaging in new tasks, i.e., via leadership training.

Third, the development of problem-solving and decision-making skills among hotel employees occurs at all times. The development of employees in this skill must be embedded in such individuals. By confronting face-to-face problems, for instance, employees must exercise their aptitude and address inflexible decision-making. In addressing short-term problems, employees improve their analytical skills, identify causal factors, and view problems as challenges that require creative thinking. For those seeking improving problem-solving skills from employees, courses can help employees improve their problem-solving and decision-making skills from every level of an organization.

Finally, regarding the development of teamwork skills for hotel employees working with internal and cross-departmental contacts, hotel operations cannot 
rely on one individual's work alone, as they rely on collaboration. Therefore, teamwork is essential to an organization accomplishing its goals. Hotels can organize activities, especially workshops, designed for their employees to practice and develop their teamwork skills. Role-playing activities focused on working across departments of an organization are essential, as employees can then understand their own and their colleagues' roles and responsibilities, allowing employees to contribute ideas on how to address problems together. Such workshops can also help employees to understand personal differences, respect and accept ideas raised by others, reduce conflict, develop a positive approach to problems, and manage personal conflicts with intelligence and equality.

Hotels should place a greater emphasis on their employees' professional skills development, especially on their social skills. This study illustrates that although employees of 5-star hotels have already attained a high level of professional and social skill, continual employee improvement should be considered. Training and workshops, for example, in professional skills improvement can influence employees' development in learning organizations. As statistically proven here, employees' professional and social skills improvement results in the development of more effective performance of learning organizations.

\section{References}

[1]. Bhaskar, A. U., \& Mishra, B. (2017). Exploring relationship between learning organizations dimensions and organizational performance. International Journal of Emerging Markets, 12(3),593-609.

[2]. Visser, M., \& Van der Togt, K. (2016). Learning in public sector organizations: A theory of action approach. Public Organization Review, 16(2), 235249.

[3]. Kunasegaran, M., Ismail, M., Rasdi, R. M., Ismail, I. A., \& Ramayah, T. (2016). Talent Development Environment and Workplace Adaptation: The Mediating Effects of Organisational Support. European Journal of Training and Development, 40(6), 370-389.

[4]. Örtenblad, A. (2018). What does "learning organization" mean? The Learning Organization, 25(3), 150-158.

[5]. Casner-Lotto, J., \& Barrington, L. (2006). Are they really ready to work? Employers' perspectives on the basic knowledge and applied skills of new entrants to the 21st century US workforce. Partnership for 21st Century Skills. 1 Massachusetts Avenue NW Suite 700, Washington, DC 20001.

[6]. Stewart, T. A. (1997). Intellectual capital: the new wealth of organizations. Doubleday Currency, New York.
[7]. NCDC. (2018). 2018 Employer Needs Survey.

Retrieved from:

https://files.nc.gov/nccommerce/documents/files/2018 -employer-needs-survey.pdf

[accessed: 10 May 2021].

[8]. Wats, M., \& Wats, R. K. (2009). Developing soft skills in students. International Journal of Learning, 15(12).

[9]. Cobo, C. (2013). Mechanisms to identify and study the demand for innovation skills in world-renowned organizations. On The Horizon-The Strategic Planning Resource for Education Professionals, 21(2), 96-106.

[10]. Busenan, E. F. M., Ramli, A., \& Bakar, M. S. (2018). Intellectual capital and its importance to the public sector. Journal of Global Business and Social Entrepreneurship (GBSE), 4(10).

[11]. Khan, A. A., \& Nouman, M. (2019). Intellectual capital in practice in the public sector: Developing a conceptual framework for the 'Third Wave'. Business \& Economic Review, 11(2), 1-18.

[12]. Mikuła, B. (2020). Instrumental approach in human capital management: A conceptual framework. Management, 8(4), 267-283.

[13]. Yusoff, Y. M., Omar, M. K., Zaman, M. D. K., \& Samad, S. (2019). Do all elements of green intellectual capital contribute toward business sustainability? Evidence from the Malaysian context using the Partial Least Squares method. Journal of Cleaner Production, 234, 626-637.

[14]. Alison, D. (2020). What Are Soft Skills?

Retrieved from:

https://www.thebalancecareers.com/what-are-softskills-2060852 [accessed: 15 June 2021].

[15]. Brungardt, C. (2011). The Intersection between Soft Skill Development and Leadership Education. Journal of Leadership Education, 10(1), 1-22.

[16]. Riggio, R. E., \& Tan, S. J. (Eds.). (2013). Leader interpersonal and influence skills: The soft skills of leadership. Routledge.

[17]. Gerbner, G. (1956). Toward a general model of communication. Audio visual communication review, 171-199.

[18]. Hovland, C. I., Janis, I. L., \& Kelley, H. H. (1953). Communication and persuasion; psychological studies of opinion change. New Haven, CN: Yale University Press.

[19]. Etzioni, A. (1964). Modern Organization. Englewood Cliffs, NJ: Prentice-Hall.

[20]. Knapp, M. L., Hall, J. A., \& Horgan, T. G. (2014). Nonverbal Communication in Human Interaction. (8th ed.). Boston, MA: Wadsworth Cengage Learning.

[21]. Pancasila, I., Haryono, S., \& Sulistyo, B. A. (2020). Effects of work motivation and leadership toward work satisfaction and employee performance: Evidence from Indonesia. The Journal of Asian Finance, Economics and Business, 7(6), 387-397.

[22]. Bass, B. M., \& Avolio, B. J. (Eds.). (1994). Improving organizational effectiveness through transformational leadership. Sage.

[23]. Gagné, R. M. (1985). Conditions of learning and theory of instruction. Holt, Rinehart and Winston. 
[24]. Morgan, C. T. (1978). Thinking and Problem Solving; A Brief Introduction to Psychology (2nd ed.). New Delhi: Tata McGrew.

[25]. Parker, G. M. (1990). Team players and teamwork. San Francisco, CA, USA:: Jossey-Bass.

[26]. HA, V. D. (2020). The impacts of empowerment on the teamwork performance: Evidence from commercial banks in Vietnam. The Journal of Asian Finance, Economics and Business, 7(4), 267-273.

[27]. P. M. Senge (1990) The Fifth Discipline: The Art and Practice of the Learning Organization Doubleday/Currency New York

[28]. Pedler, M., Burgoyne, J., \& Boydell, T. (1991). The learning company: a strategy for sustainable development. New York: McGraw-Hill.

[29]. Khlif, H., Guidara, A., \& Souissi, M. (2015). Corporate social and environmental disclosure and corporate performance. Journal of Accounting in Emerging Economies, 5(1), 51.

[30]. Tjahjadi, B., Soewarno, N., \& Gunawan, G. M. (2020). Effect of information capital readiness on business performance in Indonesian MSMEs: does online market orientation matter?. Journal of Asian Finance, Economics and Business, 7(12), 267-274.

[31]. Dzenopoljac, V., Yaacoub, C., Elkanj, N., \& Bontis, N. (2017). Impact of intellectual capital on corporate performance: Evidence from the Arab region. $J$. Intellect. Cap., 18, 884-903.

[32]. Bogićević, J., Domanović, V., \& Krstić, B. (2016). The role of financial and non-financial performance indicators in enterprise sustainability evaluation. Ekonomika, 62(3), 1-13.
[33]. Park, S., \& Choi, E. (2015). Structural Relationships among SEM CEO's Positive Leadership, Members' Positive Life Positions, Learning Organization Activities, Job Engagement, and Organizational Performance. Journal of Distribution Science, 13(12), 113-131.

[34]. Diamantopoulos, A. (1994). Modelling with LISREL: A guide for the uninitiated. Journal of Marketing Management, 10(1-3), 105-136.

[35]. Schermelleh-Engel, K., Moosbrugger, H., \& Müller, H. (2003). Evaluating the fit of structural equation models: Tests of significance and descriptive goodness-of-fit measures. Methods of psychological research online, $8(2), 23-74$.

[36]. Huang, P., \& Yao, C. (2017). Effect of learning organization on organizational communication and organizational creativity in high-Tech Industry. Eurasia Journal of Mathematics, Science and Technology Education, 13(12), 7723-7730.

[37]. Bucic, T., Robinson, L., \& Ramburuth, P. (2010). Effects of leadership style on team learning. Journal of Workplace Learning, 22(4), 228-248.

[38]. Mumford, M. D., Hester, K. S., Robledo, I. C., Peterson, D. R., Day, E. A., Hougen, D. F., \& Barrett, J. D. (2012). Mental models and creative problemsolving: The relationship of objective and subjective model attributes. Creativity Research Journal, 24(4), 311-330.

[39]. Guchait, P., Lei, P., \& Tews, M. J. (2016). Making teamwork work: Team knowledge for team effectiveness. The Journal of psychology, 150(3), 300-317. 